\title{
Analisis Pendapatan Usaha Ikan Nila (Oreochromis Niloticus) dengan Pemberian Pakan Pelet Organik (Ppo) dari Bahan Limbah Feses Sapi, Bungkil Kedelai, Dedak, dan Probiotik
}

\author{
Income Analysis of Raising Tilapia Fishes (Oreochromis Niloticus) Fed \\ Organic Pelet Feed (Opf) Composed by Cattle Feces, \\ Soybean Meal, Rice Bran, and Probiotic
}

\author{
M. Khomarun Zaman ${ }^{1}$, M. Aman Yaman ${ }^{1}, Z_{\text {Zulfan }}{ }^{\text {* }}$ \\ ${ }^{1}$ Program Studi Peternakan, Fakultas Pertanian, Universitas Syiah Kuala
}

\begin{abstract}
Abstrak. Tujuan penelitian ini adalah untuk melihat pengaruh penggunaan limbah feses sapi+bungkil kedelai+dedak+probiotik sebagai bahan Pakan Pelet Organik (PPO) terhadap keuntungan usaha pemeliharaan ikan nila (Oreochromis niloticus). Penelitian dilakukakan di Station Riset II Ie Sueum, Universitas Syiah Kuala tanggal 1 Juni-29 Agustus 2016. Materi yang digunakan adalah bibit ikan nila umur 1 minggu sebanyak 1.600 ekor. Penelitian menggunakan Rancangan Acak Lengkap (RAL) terdiri 4 perlakuan dan 4 ulangan. Tiap ulangan merupakan unit percobaan yang masing-masing terdiri 100 ekor nila. Perlakuan yang dicobakan adalah ransum komersil HI-PRO-VITE 781 yang disubstitusi dengan PPO sebanyak 0, 10, 20, dan 30\%. Komposisi PPO terdiri dari feses sapi 50\%+dedak halus 30\%+bungkil kedelai 19\%+probiotik 1\%. Parameter yang diamati adalah berat badan akhir, total konsumsi ransum, Income over Feed Cost (IOFC) dan total income. Data parameter produksi yang diperoleh dianalisis dengan Analysis of Variance (ANOVA), jika didapatkan perbedaan yang nyata, dilanjutkan dengan Uji Jarak Berganda Duncan (Ott, 1993). Data parameter ekonomis dianalisis dengan $\mathrm{R} / \mathrm{C}$ dan $\mathrm{B} / \mathrm{C}$ ratio (Soekartawi, 1995). Hasil penelitian memperlihatkan bahwa PP0 dapat digunakan sampai 20\% untuk mensubstitusi ransum komersil dalam pemeliharaan ikan nila dengan level substitusi terbaik adalah $10 \%$ yang memberikan hasil sangat nyata $(\mathrm{P}<0,01)$ meningkatkan berat badan ikan nila. Pakan Pelet Organik (PP0) layak dan menguntungkan digunakan untuk mensubstitusi sebagian ransum komersil ikan nila dengan level substitusi paling menguntungkan adalah $10 \%$.
\end{abstract}

Kata kunci: feces, nila, IOFC, income

Abstract. The objective of present study was to determine effect of feeding tilapia fishes (Oreochromis niloticus) with the commercial diets partially substituted by Organic Pelet Feed (OPF) composed by cattle feces, soybean meal, rice bran, and probiotic on total income. The study was conducted in Research Station II Ie Sueum, Syiah Kuala University, June 1 until August 29, 2016. The study used 1600 of a week old of tilapia fish. The study was performed into completely randomized design (CRD) consisting of 4 treatments and 4 replications. Each replication was an experimental unit, consisting of 100 fishes. The treatment tested was feeding tilapia fishes with commercial diets partially substituted by OPF with the level of $0,10,20$, and $30 \%$, respectively. The OPF was made up of cattle feces 50\%+rice bran 30\%+soybean meal $19 \%$-probiotic $1 \%$. Parameters measured were final body weight (FBW), total feed consumption (TFC), and Income Over Feed Cost (IOFC) as well as total income. The data of FBW and TFC were analyzed by Analysis of Variance (ANOVA) (Ott, 1993), while the data of IOFC and total income were analyzed by the economical parameters of R/C and B/C ratio (Soekartawi, 1995). The results of study showed that OPF could be used up to $20 \%$ to substitute commercial diet in raising tilapia fish with the best level was $10 \%$ most significantly $(\mathrm{P}<0,01)$ increasing body weight of tilapia fish. It was considered that the highest income of raising tilapia fish was resulted by administrating $10 \% \mathrm{OPF}$.

Key words: feces, tilapia, IOFC, income 


\section{PENDAHULUAN}

Feses sapi merupakan hasil sampingan yang berasal dari sisa-sisa bahan pakan yang tidak tercerna yang dikeluarkan dari saluran pencernaan ternak. Pada umumnya, feses sapi dimanfaatkan untuk pembuatan pupuk organik dan biogas. Feses sapi dapat juga dijadikan sebagai bahan makanan ikan. Hal ini mengingat di dalam feses sapi masih mengandung unsur-unsur hara (Salundik dan Simamora 2006) yang dapat dimanfaatkan untuk makanan ikan. Penggunaan feses sapi dimaksudkan untuk menurunkan biaya pakan dalam pemeliharaan ikan.

Bungkil kedelai merupakan hasil sampingan dari pabrik minyak kedelai yang mengandung protein cukup tinggi, sekitar 43,44\% (Hartadi et al., 1980). Penggunaan bungkil kedelai dapat menaikkan kandungan protein di dalam pakan karena ikan membutuhkan protein yang cukup tinggi untuk pertumbuhannya. Sedangkan, dedak halus merupakan hasil sampingan dari penggilingan padi yang harganya sangat murah dan ketersediaannya berlimpah. Penggunaan dedak halus dapat menurunkan harga pakan.

Salah satu jenis ikan yang baik untuk dibudidayakan adalah ikan nila (Oreochromis niloticus). Ikan ini merupakan jenis ikan air tawar yang cocok untuk kondisi iklim di Indonesia dan memiliki toleransi terhadap salinitas sehingga ikan ini dapat hidup dan berkembang biak di perairan payau dengan salinitas 20-25 ppt (Setyo, 2006). Berdasarkan uraian di atas, penelitian penggunaan Pakan Pelet Organik (PPO) berupa campuran feses sapi+bungkil kedelai+dedak halus+probiotik sebagai substitusi sebagian ransum komersil perlu dilakukan untuk melihat seberapa ekonomis pemeliharaan ikan nila.

\section{MATERI DAN METODE PENELITIAN}

\section{Tempat dan Waktu Penelitian}

Penelitian ini dilakukan di Station Riset II Ie Sueum, Universitas Syiah Kuala, Darussalam, Banda Aceh. Penelitian berlangsung selama 90 hari, mulai tanggal 1 Juni sampai 29 Agustus 2016.

\section{Materi Penelitian}

Penelitian ini menggunakan bibit ikan nila sebanyak 1.600 ekor umur 1 minggu dengan berat rata-rata 1,35 gram yang dipesan melalui Poultry Shop yang ada di Banda Aceh.

\section{Metode Penelitian}

a. Tahap persiapan: Tahap persiapan terdiri dari penyiapan pakan dan kolam. Penyiapan pakan berupa pembuatan Pakan Pelet Organik (PPO) yang tersusun dari bahan feses sapi, bungkil kedelai, dedak halus, dan probiotik dan pencampuran ransum perlakuan. Penyiapan kolam berupa pemasangan terpal yang dilanjutkan dengan proses perendaman kolam untuk 
menghilangkan bau terpal dan tumbuhnya jentik nyamuk sebagai pakan pertama ikan nila.

b. Tahap Pemeliharaan: Tahap pemeliharaan dibagi dua periode, yakni starter (0-2 minggu) dan grower+finisher (3-12 minggu). Ikan dengan ukuran $43,67 \pm 1,35$ g/ekor ditebar ke dalam keramba penelitian dengan kepadatan 100 ekor/perlakuan. Sebelum penelitian, ikan diadaptasikan dengan pakan uji sampai kenyang (at station) pada pagi, siang, dan sore hari dengan pemberian sedikit demi sedikit untuk menghindari adanya pakan yang terbuang atau tidak termakan. Selama periode 1-2 minggu, ikan nila diberikan $100 \%$ pakan komersil berupa Pelet pabrikan (781 HI-PRO-VITE). Selama 3-12 minggu, ikan diberikan Pakan Pelet Organik sebagai substitusi sebagian pakan komersil sesuai perlakuan masing-masing.

c. Tahap Pengambilan Data: Tahap pengambilan data dilakukan sejak awal penelitian hingg akhir penelitian. Data yang diambil selama penelitian adalah harga dan pemakaian input-input produksi selama penelitian seperti ikaan nila, terpal, dan pakan. Data yang diambil pada akhir penelitian adalah berat badan akhir, total konsumsi pakan dan harga jual ikan. Semua ikan tiap unit ditimbang untuk mengetahui berat badan akhirnya. Harga jual ikan ditentukan berdasarkan harga jual yang berlaku di pasaran pada saat penelitian.

\section{Analisis Statistik}

Data aspek produksi yang diperoleh diolah secara statistik dengan menggunakan analysis of variance (ANOVA). Jika diantara perlakuan terdapat perbedaan yang nyata $\left(\mathrm{F}_{\text {obs. }}>\mathrm{F}_{\text {tab. }} \alpha_{=0.05}\right)$ maka dilakukan uji lanjut dengan menggunakan Uji Jarak Berganda Duncan (Duncan Multiple Range Test) dengan prosedur $\mathrm{W}_{\mathrm{r}}^{\prime}=\mathrm{q}_{\alpha}^{\prime}(\mathrm{r}, \mathrm{v}) \sqrt{ }\left(\mathrm{s}^{2}{ }_{\mathrm{W}} / \mathrm{n}^{\prime}\right)(\mathrm{Ott}, 1993)$. Data yang memiliki tingkat perbedaan keragaman yang besar dilakukan Uji Keragaman Harley's Test $\left(\mathrm{F}_{\max }=\mathrm{s}^{2}{ }_{\max } / \mathrm{s}^{2}{ }_{\min }\right)$. Jika terdapat perbedaan keragaman yang nyata lebih besar diantara perlakuan

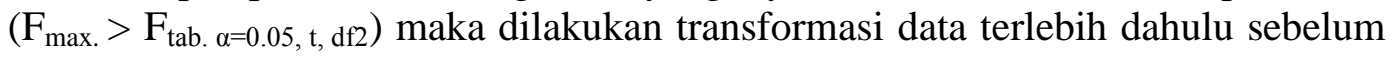
dilakukan Anova (Ott, 1993).

Data aspek ekonomis dianalisis dengan cara melihat kelayakan pemeliharaannya, yang dihitung pada $\mathrm{R} / \mathrm{C}$ ratio dan $\mathrm{B} / \mathrm{C}$ ratio (Soekartawi, 1995). Jika $\mathrm{R} / \mathrm{C}>1$ dan $\mathrm{B} / \mathrm{C}>0$ berarti layak dan menguntungkan. Jika $\mathrm{R} / \mathrm{C}<$ 1 dan $\mathrm{B} / \mathrm{C}<0$ berarti tidak layak dan rugi (Soekartawi, 1995).

$$
\begin{aligned}
& \mathrm{R} / \mathrm{C}=\mathrm{P}_{\mathrm{Q}} \cdot \mathrm{Q} /(\mathrm{TFC}+\mathrm{TVC}) \\
& \mathrm{B} / \mathrm{C}=\mathrm{R}-(\mathrm{TFC}+\mathrm{TVC}) /(\mathrm{TFC}+\mathrm{TVC})
\end{aligned}
$$

Keterangan:

$\mathrm{R}$ : penerimaan

C : biaya

B : keuntungan

$\mathrm{P}_{\mathrm{Q}} \quad$ : harga output

$\mathrm{Q} \quad$ : output

TFC : biaya tetap (fixed cost) 
TVC : biaya variabel (variable cost)

\section{HASIL DAN PEMBAHASAN}

\section{Aspek Produksi Pemeliharaan Ikan Nila}

Aspek produksi ikan nila yang sangat berkaitan dengan analisis aspek ekonomi adalah total konsumsi ransum selama pemeliharaan dan berat badan akhir pemeliharaan. Oleh karena itu, kedua parameter tersebut dianalisis terlebih dahulu. Konsumsi ransum dan bobot badan akhir ikan nila yang diberi ransum komersil yang disubstitusi dengan Pakan Pelet Organik (PPO) yang tersusun dari bahan limbah feses sapi+bungkil kedelai+dedak halus+probiotik selama pemeliharaan 12 minggu diperlihatkan pada Tabel 7.

Tabel 7. Konsumsi Ransum dan Berat Badan Akhir Ikan Nila yang Dipelihara dengan Pemberian Ransum Komersil HI-PRO-VITE 781-2 dengan Substitusi Pakan Pelet Organik (PPO) (g/ekor)

\begin{tabular}{ccccc}
\hline \multirow{2}{*}{ Parameter } & \multicolumn{4}{c}{ Perlakuan } \\
\cline { 2 - 5 } & $\mathrm{P}_{0}$ & $\mathrm{P}_{1}$ & $\mathrm{P}_{2}$ & $\mathrm{P}_{3}$ \\
\hline Konsumsi ransum & $27,25 \pm 1,18^{\mathrm{ab}}$ & $37,29 \pm 2,75^{\mathrm{c}}$ & $31,26 \pm 2,63^{\mathrm{b}}$ & $24,10 \pm 1,36^{\mathrm{a}}$ \\
Berat badan akhir & $30,30 \pm 0,98^{\mathrm{a}}$ & $43,70 \pm 4,13^{\mathrm{b}}$ & $31,20 \pm 3,47^{\mathrm{a}}$ & $18,98 \pm 1,59^{\mathrm{c}}$ \\
\hline $\mathrm{P}_{0}=100 \%$ ransum komersil HI- PRO-VITE 781-2 (kontrol) \\
$\mathrm{P}_{1}=90 \%$ ransum komersil HI- PRO-VITE 781-2 + 10\% Pakan Pelet Organik (PPO) \\
$\mathrm{P}_{2}=80 \%$ ransum komersil HI- PRO-VITE 781-2 + 20\% Pakan Pelet Organik (PPO) \\
$\mathrm{P}_{3}=70 \%$ ransum komersil HI- PRO-VITE 781-2 + 30\% Pakan Pelet Organik (PPO)
\end{tabular}

\section{Konsumsi Ransum}

Perbedaan tingkat konsumsi ransum ini mempengaruhi pertumbuhan ikan yang dapat dilihat dari capaian berat badan akhirnya.

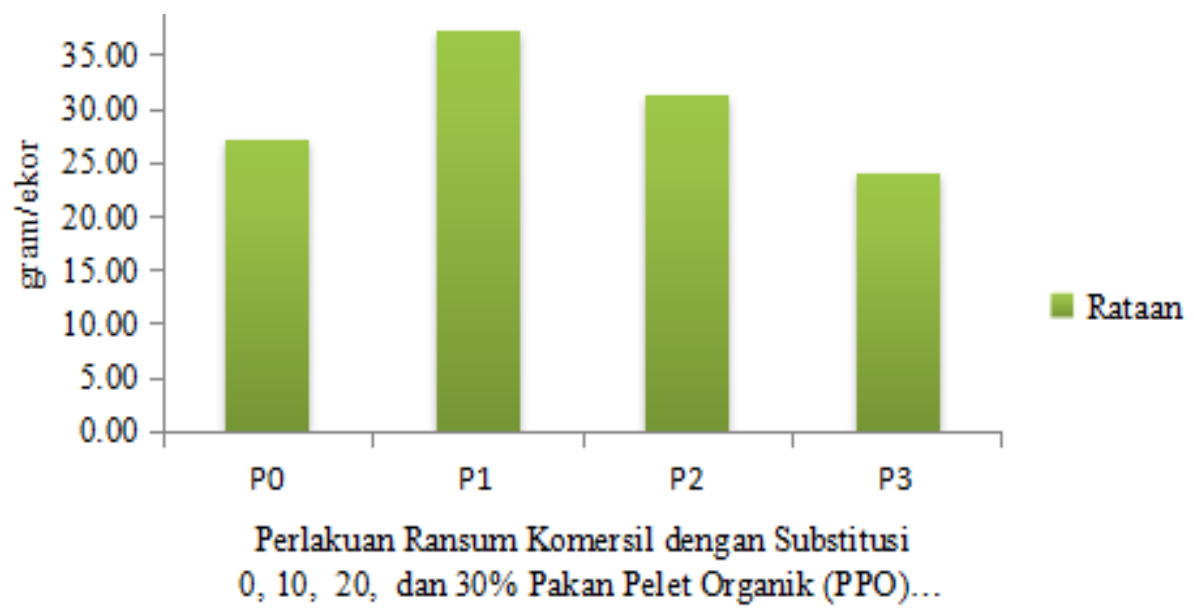

Analisis Pendapatan Usaha Ikan Nila (Oreochromis Niloticus) dengan Pemberian Pakan Pelet Organik (Ppo) Dari Bahan Limbah Feses Sapi, Bungkil Kedelai, 
Gambar 5. Konsumsi Ransum Ikan Nila Selama Pemeliharaan 0-12 Minggu dari Semua Perlakuan

Seperti yang dinyatakan oleh Widiyati dan Sunarno (2010), tingkat konsumsi pakan pada ikan dipengaruhi oleh faktor pakan seperti bentuk pakan, respon ikan terhadap aroma, rasa dan tekstur pakan yang mempengaruhi penerimaan pakan tersebut oleh ikan. Faktor suhu dapat juga mempengaruhi konsumsi pakan misalnya nafsu makan ikan (Effendi, 2003 dan Mulyani et al., 2014). Dalam penelitian ini, kondisi suhu untuk semua kolam perlakuan adalah sama. Dengan demikian, kemungkinan besar terjadinya perbedaan konsumsi ransum ikan perlakuan dalam penelitian ini adalah faktor pakannya. Pakan komersil yang disubstitusi dengan $10 \%$ PPO $\left(\mathrm{P}_{1}\right)$ lebih dapat diterima oleh ikan. Akan tetapi, jika PPO terlalu banyak digunakan (melebihi 10\%), ikan mulai menunjukkan penolakan terhadap pakan tersebut. Penolakan yang jelas terlihat ketika PPO digunakan sampai 30\% $\left(\mathrm{P}_{3}\right)$.

\section{Berat Badan Akhir}

Dari hasil penelitian ini, pertumbuhan ikan nila yang paling baik adalah pada substitusi $10 \%$ ransum komersil dengan PPO $\left(\mathrm{P}_{1}\right)$ karena memiliki berat badan akhir paling tinggi. Pada level ini, kualitas ransum diperkirakan menjadi lebih baik, namun jika PPO digunakan melebihi 10\%, kualitas ransum menjadi menurun. Menurut Widiyati dan Sunarno (2010), kualitas pakan sangat menentukan performan pakan. Menurut Batu (1982), nutrisi adalah bahan baku yang dibutuhkan demi kelangsungan hidup suatu organisme, digunakan oleh selsel tubuh untuk pembentukan bagian tubuh dan untuk energi dan metabolisme suatu organisme.

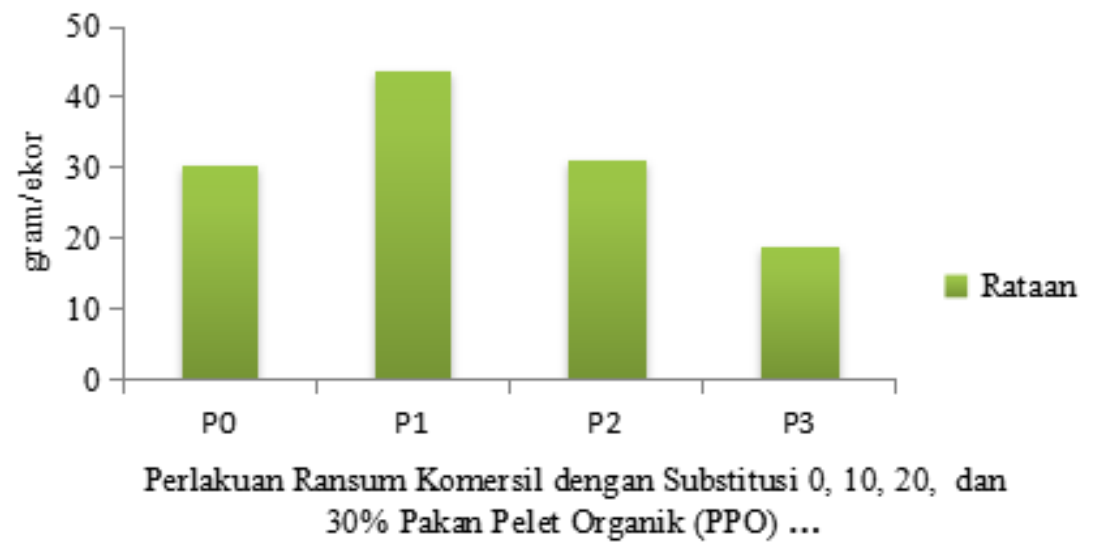

Gambar 6. Rataan Berat Badan Akhir Ikan Nila pada Umur 12 Minggu dari Semua Perlakuan 
Tingkat konsumsi protein (protein intake) dapat dihitung dari kandungan protein di dalam pakan (Tabel 5) dan tingkat konsumsi pakan (Tabel 7). Hasil perhitungan rata-rata protein intake selama pemeliharaan 12 minggu dari masingmasing perlakuan adalah 8,45-8,99 $\left(\mathrm{P}_{0}\right), 11,79-12,46\left(\mathrm{P}_{1}\right), 10,07-10,57\left(\mathrm{P}_{2}\right)$, dan 7,91-8,24 g/ekor $\left(\mathrm{P}_{3}\right)$. Jelas terlihat bahwa ikan-ikan yang mengkonsumsi ransum komersil dengan substitusi $10 \%$ PPO $\left(\mathrm{P}_{1}\right)$ memiliki rata-rata konsumsi proten lebih tinggi daripada perlakuan lainnya. Hal inilah yang mendukung ikan-ikan dari perlakuan tersebut mencapai berat badan paling tinggi di antara semua perlakuan. Pengambilan protein menjadi berkurang ketika level PPO ditingkatkan menjadi 20\% $\left(\mathrm{P}_{2}\right)$ sehingga berat badannya juga menurun tetapi sedikit masih lebih tinggi daripada kontrol $\left(\mathrm{P}_{0}\right)$. Pengambilan protein sangat drastis berkurang ketika level PPO ditingkatkan menjadi 30\% $\left(\mathrm{P}_{3}\right)$ menyebabkan berat badannya juga menurun di bawah kontrol $\left(\mathrm{P}_{0}\right)$. Hasil penelitian ini menunjukkan bahwa Pakan Pelet Organik (PPO) yang tersusun dari bahan limbah feses sapi+bungkil kedelai+dedak halus+probiotik dapat digunakan untuk mensubstitusi ransum komersil dengan level penggunaan terbatas yakni maksimal $10 \%$.

\section{Aspek Ekonomi Pemeliharaan Ikan Nila}

Salah satu cara untuk melihat apakah suatu usaha pemeliharaan ikan nila yang diberikan ransum komersil HI-PRO-VITE + Pakan Pelet Organik (PPO) yang tersusun dari bahan limbah feses sapi+bungkil kedelai+dedak halus+probiotik layak atau tidak adalah dengan cara menganalisis ekonomi pemeliharaan ikan nila tersebut. Aspek ekonomi pemeliharaan ikan nila yang diberikan ransum komersil HI-PRO-VITE yang disubtitusi dengan PPO diperlihatkan pada Tabel 8-12.

\section{Penerimaan}

Berdasarkan hasil analisis, pemeliharaan ikan nila selama 12 minggu dengan pemberian ransum komersil yang disubsitusi dengan Pakan Pelet Organik (PPO) yang tersusun dari bahan limbah feses sapi+bungkil kedelai+dedak halus+probiotik maksimal $20 \% \quad\left(\mathrm{P}_{1}-\mathrm{P}_{2}\right)$ meningkatkan penerimaan bila dibandingkan dengan pemberian $100 \%$ ransum komersil $\left(\mathrm{P}_{0}\right)$. Akan tetapi, jika PPO digunakan sampai 30\% maka terjadi penurunan penerimaan. Penerimaan paling tinggi adalah pada penggunaan $10 \%$ PPO $\left(\mathrm{P}_{1}\right)$ sebagai subsitusi ransum komersil. Hal ini dikarenakan berat badan ikan paling tinggi dicapai pada level tersebut, sedangkan harga jual ikan sama untuk semua perlakuan.

Penerimaan dari penjualan ikan nila masih belum dapat digunakan untuk menggambarkan seberapa ekonomis pemeliharaan ikan nila selama 12 minggu dengan menggunakan pakan substitusi PPO. Oleh karena itu perlu dihitung biaya (cost) yang diperlihatkan pada Tabel 9. Penerimaan masih dapat dinyatakan sebagai pendapatan kotor dari hasil penjualan ikan nila (g/ekor) yang belum dikurangi dengat total biaya (total cost) pengeluaran (Soekartawi, 1995). 


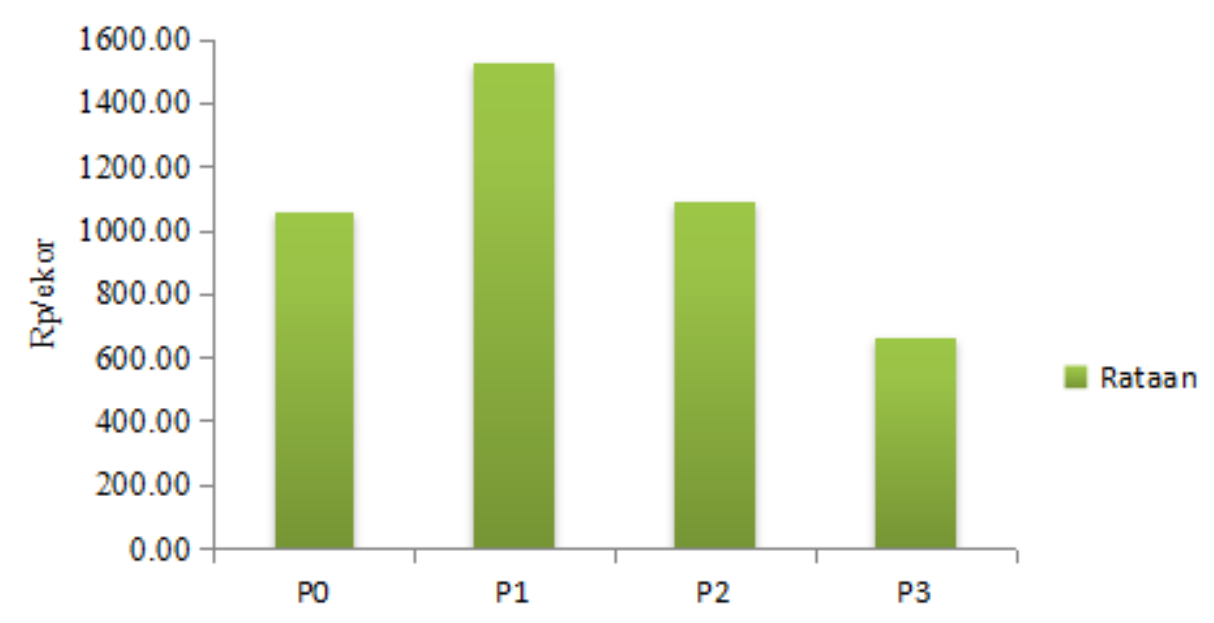

Perlakuan Ransum Komersil dengan Substitusi

$0,10,20$, dan $30 \%$ Pakan Pelet Organik (PPO)

Gambar 7. Total Hasil Penerimaan dari Pemeliharaan Ikan Nila untuk Semua Perlakuan pada Umur 12 Minggu

\section{Biaya-Biaya}

Hasil analisis memperlihatkan bahwa adanya perubahan total biaya pemeliharaan ikan nila selama 12 minggu yang diberi ransum komersil dengan substitusi Pakan Pelet Organik (PPO) yang tersusun dari bahan limbah feses sapi+bungkil kedelai+dedak halus+probiotik. Perubahan total biaya (total cost) ini dikarenakan adanya perbedaan biaya variabel ransum (feed cost), sedangkan biaya variabel lainnya dan biaya tetap (fixed cost) tidak berubah diantara perlakuan. Perubahan dapat berupa kenaikan dan penurunan biaya ransum perlakuan PPO dibandingkan dengan pemeliharaan ikan yang diberi ransum komersil $100 \%\left(\mathrm{P}_{0}\right)$. Penggunaan $10 \%$ PPO $\left(\mathrm{P}_{1}\right)$ menyebabkan kenaikan biaya ransum. Jika PPO ditingkatkan sampai $20 \%\left(\mathrm{P}_{2}\right)$, biaya ransum lebih kurang sama dengan kontrol $\left(\mathrm{P}_{0}\right)$. Akan tetapi, jika PPO ditingkatkan lagi sampai $30 \%\left(\mathrm{P}_{3}\right)$, biaya ransum menjadi lebih rendah dari pada kontrol. 


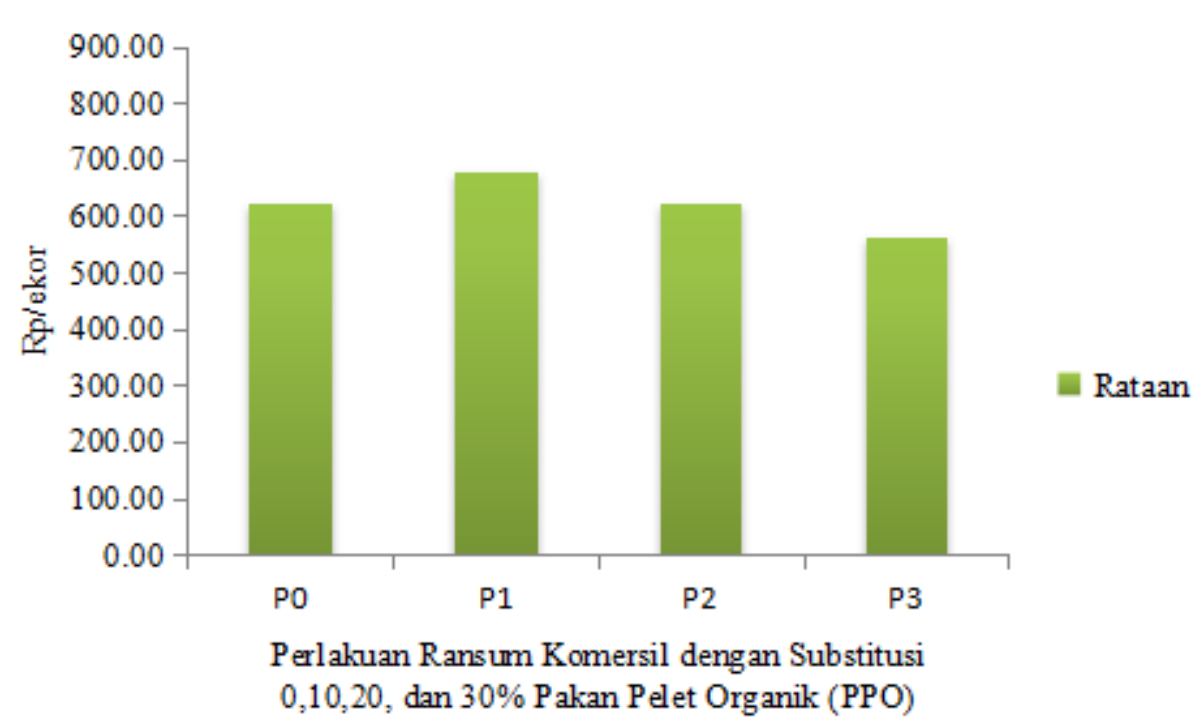

Gambar 8. Total Biaya Pemeliharaan Ikan Nila dari Semua Perlakuan Selama Pemeliharaan 0-12 Minggu

Terjadinya kenaikan biaya ransum pada penggunaan $10 \%$ PPO $\left(\mathrm{P}_{1}\right)$ disebabkan konsumsi ransum yang sangat nyata lebih tinggi meskipun harga ransumnya lebih rendah dibandingkan dengan harga ransum komersil. Sedangkan terjadinya penurunan biaya ransum pada penggunaan $30 \%$ PPO $\left(\mathrm{P}_{3}\right)$ disebabkan konsumsi ransum yang sangat nyata lebih rendah dan harga ransumnya lebih rendah pula. Biaya ransum yang tinggi ataupun rendah belum dapat digunakan untuk melihat tingkat keuntungan dari penggunaan ransum. Oleh karena itu, penghitungan Income over Feed Cost (IOFC) diperlukan untuk melihat sejauh mana pengaruh penerimaan dan biaya ransum terhadap tingkat keuntungan.

\section{IOFC dan Total Income}

Hasil analisis memperlihatkan bahwa terjadinya perubahan Income over Feed Cost (IOFC) dari pemeliharaan ikan nila dengan pemberian ransum komersil yang disubstitusi dengan Pakan Pelet Organik (PPO). Pemeliharaan ikan nila dengan penggunaan maksimal $20 \%$ PPO $\left(\mathrm{P}_{1}-\mathrm{P}_{2}\right)$ sebagai substitusi ransum komersil menghasilkan IOFC yang lebih tinggi dibandingkan dengan penggunaan pakan komersil $100 \%\left(\mathrm{P}_{0}\right)$. Nilai IOFC paling tinggi adalah pada penggunaan $10 \%$ PPO $\left(\mathrm{P}_{1}\right)$. Pada penggunaan $20 \%$ PPO $\left(\mathrm{P}_{2}\right)$, nilai IOFC masih lebih tinggi daripada kontrol, namun sedikit sekali perbedaannya. Akan tetapi, jika PPO digunakan sampai $30 \%$ untuk mensubstitusi ransum komersil, IOFC menjadi menurun.

Perhitungan IOFC belum dapat menggambarkan nilai keuntungan yang sebenarnya karena IOFC hanya memperhitungkan keuntungan dari pemeliharaan ikan terhadap pemberian ransum. Oleh karena itu, analisis total income perlu dilakukan agar dapat diketahui keuntungan yang sebenarnya dari hasil penerimaan dikurangi dengan total cost. Berdasarkan hasil analisis terlihat bahwa pemberian 
Pakan Pelet Organik (PPO) dapat menghasilkan keuntungan yang lebih tinggi jika digunakan tidak melebihi $20 \%$.

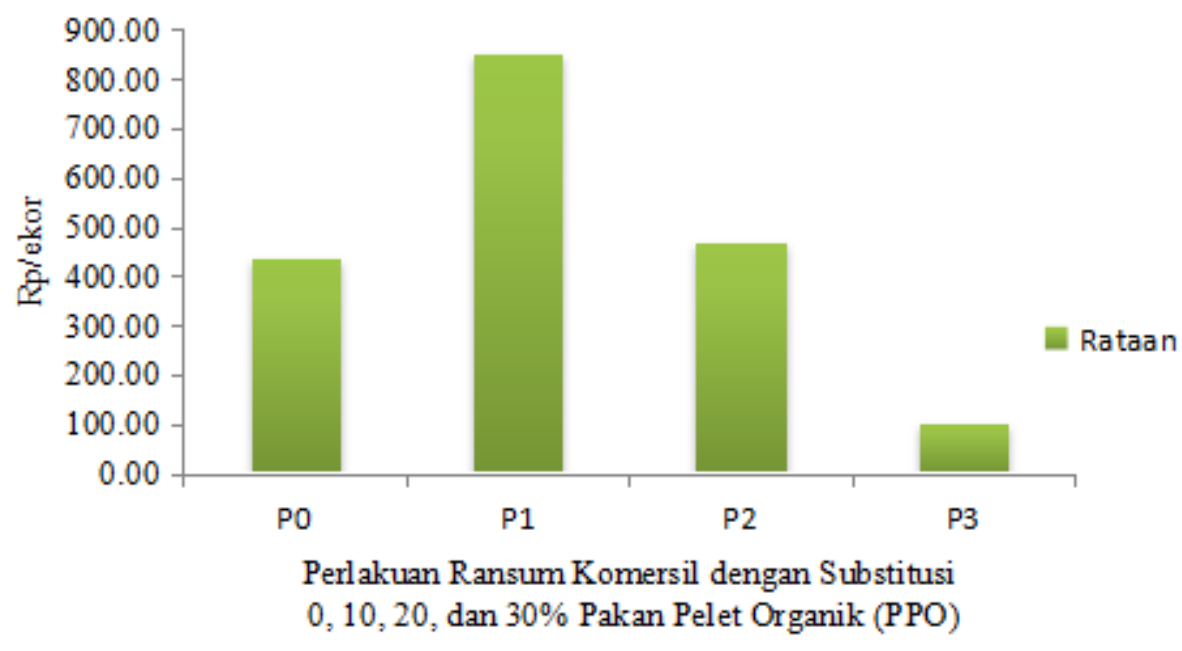

Gambar 9. Total Income Pemeliharaan Ikan Nila Selama

Pemeliharaan 0-12 Minggu dari Semua Perlakuan

Keuntungan paling tinggi adalah pada penggunaan $10 \%$ PPO $\left(\mathrm{P}_{1}\right)$ sebagai substitusi ransum komersil yang keuntungannya dua kali lebih besar daripada penggunaan $100 \%$ ransum komersil $\left(\mathrm{P}_{0}\right)$. Besaran keuntungan ini sudah dapat digunakan untuk melihat layak atau tidaknya penggunaan PPO sebagai substitusi ransum komersil. Analisis kelayakan lainnya dapat dilihat dari nilai $\mathrm{B} / \mathrm{C}$ dan $\mathrm{R} / \mathrm{C}$ ratio.

\section{Kelayakan Pemeliharaan}

Hasil analisis kelayakan usaha memperlihatkan semua ransum layak digunakan dan menguntungkan dalam pemeliharaan ikan nila selama 12 minggu. Hal ini dikarenakan semua perlakuan memiliki nilai $\mathrm{R} / \mathrm{C}$ ratio lebih besar dari satu dan B/C ratio lebih besar dari nol. Seperti yang dikatakan oleh Sjahrial (2008), jika $\mathrm{R} / \mathrm{C}$ ratio $>1$ dan jika $\mathrm{B} / \mathrm{C}$ ratio $>0$ berarti layak usaha dan menguntungkan.

Berdasarkan hasil analisis usaha diketahui bahwa pemeliharaan ikan nila selama 12 minggu yang paling layak dan menguntungkan adalah pada penggunaan $10 \%$ PPO $\left(\mathrm{P}_{1}\right)$. Sedangkan pada perlakuan lainnya, meskipun juga menguntungkan, tingkat keuntungannya lebih sedikit terutama pada penggunaan $30 \%$ PPO $\left(\mathrm{P}_{3}\right)$. 


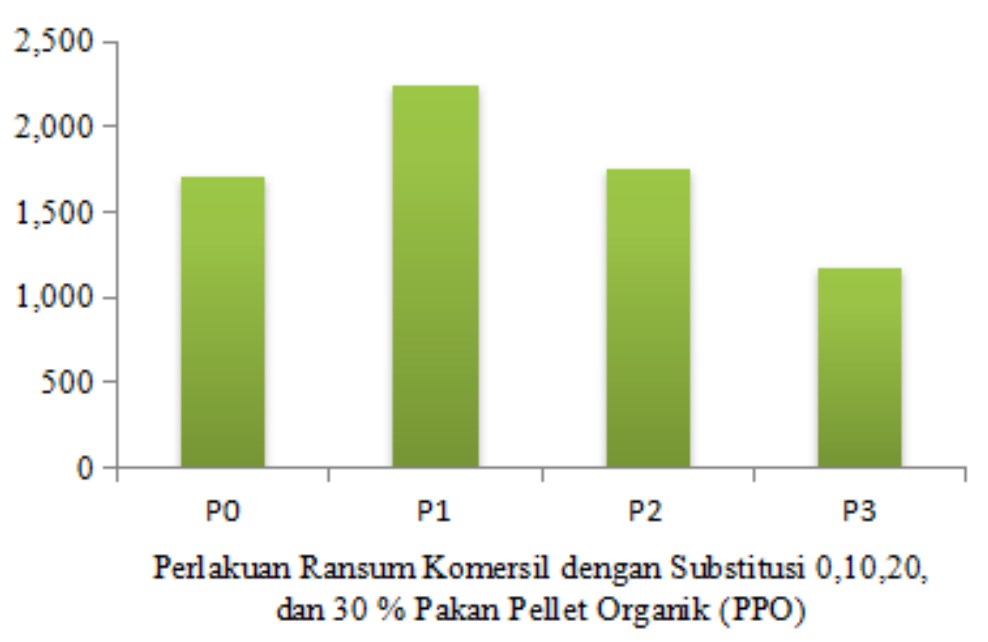

Gambar 10. R/C Ratio Pemeliharaan Ikan Nila Selama Pemeliharaan 12 Minggu dari Semua Perlakuan

\section{KESIMPULAN DAN SARAN}

\section{Kesimpulan}

Berdasarkan hasil penelitian yang dilakukan dapat disimpulkan bahwa:

1. Pakan Pelet Organik (PP0) berupa campuran feses sapi, bungkil kedelai, dedak halus halus, dan probiotik dapat digunakan hingga 20\% untuk mensubstitusi ransum komersil dalam pemeliharaan ikan nila dengan level substitusi terbaik adalah $10 \%$ yang memberikan hasil sangat nyata meningkatkan berat badan ikan nila.

2. Pakan Pelet Organik (PP0) yang tersusun dari bahan limbah feses sapi+bungkil kedelai+dedak halus+probiotik layak dan menguntungkan digunakan untuk mensubstitusi sebagian ransum komersil ikan nila dengan level substitusi paling menguntungkan adalah $10 \%$ yang memberikan keuntungan dua kali lebih besar daripada penggunaan $100 \%$ ransum komersil.

\section{Saran}

Berdasarkan hasil penelitian yang dilakukan disarankan bahwa:

1. Pemeliharaan ikan nila sebaiknya menggunakan 10\% Pakan Pelet Organik (PPO) berupa campuran feses sapi, bungkil kedelai, dedak halus halus dan probiotik sebagai substitusi ransum komersil.

2. Perlu dilakukan penelitian lanjut tentang penggunaan Pakan Pelet Organik (PPO) yang tersusun dari bahan limbah feses sapi+bungkil kedelai+dedak halus+probiotik 


\section{DAFTAR PUSTAKA}

Batu, D. T .F. L. 1982. Pengantar ke Fisiologi Hewan Air. Ed. ke-3. Departemen Hidrobiologi. Bagian Biologi Laut. Fakultas Perikanan. Institut Pertanian Bogor, Bogor.

Effendi, H. 2003. Telaah Kualitas Air. Kanisius, Yogyakarta.

Hartadi, H., S. Reksohadiprodjo, S. Lebdosukojo, dan A. D. Tillman. 1980. Tabel-Tabel dari Komposisi Bahan Makanan Ternak untuk Indonesia (Tables of Feed Composition for Indonesia). The International Feedstuff Institute. Utah Agricultural Experiment Station. Utah State University, Logan, Utah.

Widiyati, A. dan M. T. D. Sunarno. 2010. Dampak penggunaan pakan buatan terhadap keberlanjutan perikanan budidaya di perairan waduk (Studi Kasus Waduk Cirata). Disampaikan pada Acara Semiloka Nutrisi dan Teknologi Pakan Ikan/Udang, Badan Research Kelautan \& Perikanan. Ikatan Sarjana Perikanan Indonesia, Bogor.

Mulyani, Y. S., Yulisman, dan M. Fitrani. 2014. Pertumbuhan dan efisiensi pakan ikan nila (Oreochromis niloticus) yang dipuasakan secara periodik. Jurnal Akuakultur Rawa Indonesia, 2(1): 1-12.

Ott, R. L. 1993. An Introduction to Statistical Methods and Data Analysis. $4^{\text {th }}$ Ed. Duxbury Press, Belmont, California.I

Salundik dan S. Simamora. 2006, Meningkatkan Kualitas Kompos. AgroMedia Pustaka, Jakarta Selatan.

Sjahrial, D. 2008. Kumpulan Pembahasan Manajemen Keuangan. Ed. ke-1. Penerbit Mitra Wacana Medi, Jakarta.

Soekartawi. 1995. Analisis Usahatani. Universitas Indonesia, Jakarta.

Widiyati, A. dan M. T. D. Sunarno. 2010. Dampak penggunaan pakan buatan terhadap keberlanjutan perikanan budidaya di perairan waduk (Studi Kasus Waduk Cirata). Disampaikan pada Acara Semiloka Nutrisi dan Teknologi Pakan Ikan/Udang, Badan Research Kelautan \& Perikanan. Ikatan Sarjana Perikanan Indonesia, Bogor. 